\title{
Interspecific and interhabitat variation in hsp70 gene expression in native and invasive kelp populations
}

\author{
Sarah K. Henkel ${ }^{1,3, *}$ Hiroshi Kawai $^{2}$, Gretchen E. Hofmann ${ }^{1}$ \\ ${ }^{1}$ Department of Ecology, Evolution, and Marine Biology, University of California, Santa Barbara, California 93106, USA \\ ${ }^{2}$ Kobe University Research Center for Inland Seas, Iwaya 2746, Awajicho, Tsunagun, Hyogo 656-2401, Japan \\ ${ }^{3}$ Present address: Hatfield Marine Science Center, Oregon State University, 2030 SE Marine Science Dr., Newport, \\ Oregon 97365, USA
}

\begin{abstract}
This study characterized the response to thermal stress in 3 kelp species to contribute to the understanding of the role of the heat shock response in species distributions and in native-invasive species interactions. We sampled the invasive kelp Undaria pinnatifida in its native range in Japan and its introduced range in California, USA, to investigate small- and large-scale differences in its response to temperature stress. We then conducted similar experiments on native kelp species in different habitats in California to investigate differences in the response among species and habitats. We examined temperature response by measuring the induction of the gene (hsp70) that encodes for heat shock protein 70 (Hsp70), which protects cellular proteins from mis-folding and degradation by environmental stress. Individuals of $U$. pinnatifida, and the native California species Egregia menziesii and Pterygophora californica were heat-shocked at a range of temperatures, and mRNA was extracted and analyzed for expression of $h s p 70$. Significant differences in the timing and magnitude of $h s p 70$ induction were observed between intertidal and harbor populations of $U$. pinnatifida within a few meters of each other in Japan, indicating environmentally driven variability in this response. Similarly, intertidal and subtidal populations of E. menziesii showed different responses, with subtidal E. menziesii populations responding more like subtidal P. californica populations. Native California species showed similar magnitudes of expression across all population, while $U$. pinnatifida collected from California harbors exhibited a more robust $h s p 70$ response than native California species but was similar in magnitude to Japanese populations sampled.
\end{abstract}

KEY WORDS: Kelp $\cdot$ hsp70 · Invasive · Native · Thermotolerance $\cdot \mathrm{qPCR} \cdot$ Undaria

Resale or republication not permitted without written consent of the publisher

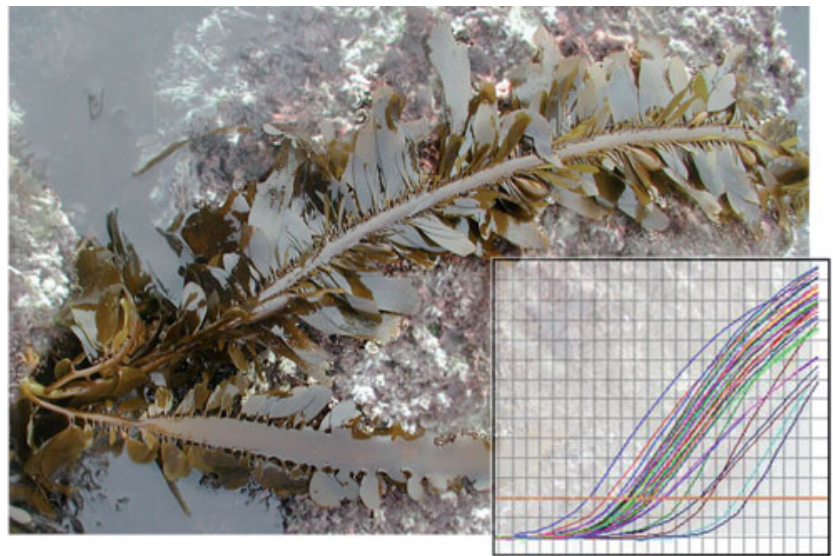

Intertidal kelp populations exhibit faster heat shock gene up-regulation than submerged populations. Inset shows PCR amplification vs. cycle.

Photo: S. Henkel

\section{INTRODUCTION}

Only a few of the many species introduced to novel habitats become invasive (Williamson 1996), suggesting the existence of a suite of characters that enable invasiveness (Bossdorf et al. 2004). A large body of literature has developed in recent years attempting to identify these key characters (Williamson \& Fitter 1996, Dukes \& Mooney 1999, Kolar \& Lodge 2001, Parker et al. 2003, Neubert \& Parker 2004, Stachowicz \& Byrnes 2006), and generally, broad tolerance, high reproductive rates, and plasticity (the ability to adjust traits to match different conditions) have been associated with invasive species. Many introduced species also become invasive after persisting for a long time at low abundances in the introduced habitat (Mack et al. 2000, 
Sakai et al. 2001), possibly after evolutionary adjustments to the novel environments (Mooney \& Cleland 2001). In order to determine if certain species possess characteristics that enhance invasiveness or if invasive populations have evolved different characteristics than source populations, it is necessary to conduct investigations of an invader in both its introduced and native ranges. To date, the majority of studies on invasive species have been conducted within their introduced ranges, and ecologists often know little about the ecology of such species in their native ranges (Hierro et al. 2005). A few studies have shown that invasive species behave differently in their new range (Perez et al. 1988, Hay \& Villouta 1993, Thornber et al. 2004), but whether that is due to a plastic response to a new environment, genetically controlled shifts in traits, founder effects, or various other factors remains uncertain.

Undaria pinnatifida, native to southeast Asia, was first identified in California, USA, in 2000 and has been found primarily in harbors from Monterey Bay, California, to Baja California, Mexico; however, 3 benthic (2 subtidal and 1 intertidal) populations are known to exist outside of harbors (Silva et al. 2002, AguilarRosas et al. 2004). As U. pinnatifida is an aquaculture species in Asia, there is a large body of literature on its reproduction (Kimura \& Notoya 1996, Liu et al. 2004, Choi et al. 2005), growth (Ishikawa 1993, Oh \& Koh 1996), and nutrition (Jurkovic et al. 1995, Goni et al. 2002). However, there is much less literature on the ecology of wild populations in its native range (but see Saito 1956, Saito 1975). Conversely, there has been a large amount of research on $U$. pinnatifida in invaded areas, as it is such a conspicuous introduced species (Boudouresque et al. 1985, Fletcher \& Manfredi 1995, Floc'h et al. 1995, Casas \& Piriz 1996, Campbell et al. 1999, Forrest et al. 2000, Casas et al. 2004, Schaffelke et al. 2005, Sliwa et al. 2006, Dean \& Hurd 2007). Lacking to date are direct comparisons of native and introduced populations. Furthermore, although many studies have investigated growth and reproductive patterns of invasive $U$. pinnatifida, molecular mechanisms for dealing with environmental stressors have been little investigated in this species. Thus, in this study, we aimed to investigate a molecular response to temperature challenges in native and introduced populations of $U$. pinnatifida as well as in native California kelp species.

In the present study we quantified the response to temperature by measuring transcriptional activation, or up-regulation, of the hsp70 gene which encodes heat shock protein 70 , a chaperone protein that protects cellular proteins from mis-folding and degradation by environmental stress (Lindquist 1986). In previous work, we found significant differences in the heat shock response between harbor and benthic, subtidal populations of introduced Undaria pinnatifida in North America (Henkel \& Hofmann 2008). For this investigation we characterized 2 main comparisons: the response to thermal stress (1) within species between different habitats, and (2) among species in their native and introduced ranges. Physiological comparisons in response to thermal stress in a variety of habitats and between native species and a competitive invader may help determine if thermal microhabitats are influential in facilitating invasions. This is especially important in benthic species such as kelps where community composition is often influenced by the order in which species colonize a habitat; thus, rising sea temperatures may give invasive species from warmer climates the competitive edge (Stachowicz et al. 2002). We conducted experiments on wild populations of $U$. pinnatifida in its native Japan as well as on introduced populations found in California harbors to investigate whether introduced populations exhibit more or less variation in their pattern of $h s p 70$ expression in response to temperature and to investigate small and large geographic scale differences in its response to temperature stress.

The comparison between native and introduced populations can help determine if thermotolerance characteristics observed in introduced populations are species traits of Undaria pinnatifida or if they are traits of a potentially invasive ecotype that make it especially successful at surviving transport and colonizing new areas. Further, studying introduced species in multiple habitats in the native range may reveal the potential level of variation in a particular response and provide a window to the future of how introduced populations will respond once they become as genetically diverse as native populations, assuming initial bottlenecks or founder effects. Comparisons to existing native species in the introduced range can help scientists make predictions about the invader's ability to compete with and possibly out-persist native species in the introduced range. If $U$. pinnatifida exhibits a greater or more plastic thermotolerance than California kelp species, then it may have the potential for persisting under scenarios of increasing ocean warming or temperature fluctuations that would negatively impact native species. Thus, we sampled the native kelp Egregia menziesii in 2 habitats in California and another native California kelp, Pterygophora californica, in a single habitat and made comparisons among all species to further examine the potential role of phylogeny.

Egregia menziesii was chosen as the first native comparison species due to its broad distribution (Alaska, USA, to Baja California, Mexico, intertidal to $15 \mathrm{~m}$; Abbott \& Hollenberg 1976), which includes a high degree of variability in temperature, nutrient, and wave exposure, and thus potential for a broad range of 
physiological responses. Thus, while a single E. menziesii population may not experience the range of temperatures likely experienced by native Undaria pinnatifida populations in the Seto Inland Sea of Japan (Yanagi 1984), the species does experience a broad range of temperatures throughout its distribution. Pterygophora californica was chosen for the second native comparison since it is in the same kelp group as U. pinnatifida (Lane et al. 2006). Comparisons between closely related native and invasive species as well as among those that are most distantly related may be interesting as the amount, array, and kinetics of Hsps produced in response to heat stress can vary widely within phylogenetic lineages (Bosch et al. 1988, Saunders et al. 1991, White et al. 1994, Gehring \& Wehner 1995). The use of both E. menziesii and P. californica as comparisons to $U$. pinnatifida enabled investigations between closely and distantly related kelp species from a variety of habitats.

We hypothesized that the responses of Undaria pinnatifida populations in California would be more similar to each other than the responses among $U$. pinnatifida sampled in Japan due to reduced genetic diversity among populations in the introduced range (Voisin et al. 2005, Uwai et al. 2006). Within California native species we hypothesized that we would observe significant differences in intertidal and subtidal population of Egregia menziesii, based on differences observed between populations of kelp collected from different habitats in our previous studies (Henkel \& Hofmann 2008). For the native versus invasive species comparison, we hypothesized that $U$. pinnatifida would respond more rapidly to temperature stress, as temperatures in the sampled region in Japan fluctuate more widely and have higher maxima than those observed in California coastal waters (Yanagi 1984). We also hypothesized that introduced $U$. pinnatifida would have a higher magnitude of hsp70 gene expression than California native species, and possibly native Japanese populations of $U$. pinnatifida, indicating a greater capacity to respond to stress events and possibly contributing to invasion success. The results presented here show a trend of heat shock gene regulation being tuned to local conditions and the invasive species, U. pinnatifida, indeed, showing higher expression than the native California species.

\section{MATERIALS AND METHODS}

Sample collection and treatment. Japan: Undaria pinnatifida ( $\mathrm{n}=5$ at each site) were collected from 4 sites ( 2 intertidal and 2 harbor) on Awaji Island in the Seto Inland Sea of Japan. Individuals were collected from one paired submerged $(\mathrm{AB}-\mathrm{H})$ and intertidal
(AB-I) site near the Asagiri bus station in Sumoto City, Hyogo Prefecture. An additional intertidal population was sampled at Etoile Oishi Park (EO-I), also in Hyogo Prefecture, and an additional submerged population was sampled at the Porphyra culturing facility on Awaji Island (PC-H). 'Submerged' sites were floating concrete dock structures where $U$. pinnatifida was collected near the zero tide line, such that they were never exposed by the tide, hereafter referred to as 'harbor' sites for comparison with U. pinnatifida collected from California harbors. Individuals were transported in coolers to the laboratory of Dr. Hiroshi Kawai of Kobe University. For the paired intertidal and harbor sites near the Asagiri bus station (AB-H and AB-I), as well as the second intertidal site at Etoile Oishi Park (EO-I), experiments were begun within $4 \mathrm{~h}$ of collection. Transportation issues returning from the Porphyra culturing facility on Awaji Island (PC-H) resulted in greater than $5 \mathrm{~h}$ of transit time during which samples were inadvertently exposed to heat stress. Thus, the PC-H samples were not suitable for analysis, unfortunately unbalancing our sampling design. Upon return to the laboratory, 150 to $200 \mathrm{mg}$ tissue from each specimen was placed in a $20 \mathrm{ml}$ scintillation vial filled with filtered seawater and placed in aluminum blocks submerged in water baths held at $\sim 12,17,22,26,30$, and $33^{\circ} \mathrm{C}$ for $1 \mathrm{~h}$. After thermal incubation, samples were rinsed in $1 \times$ phosphate-buffered saline (PBS), blotted dry, flash frozen in liquid $\mathrm{N}_{2}$, stored at $-80^{\circ} \mathrm{C}$, and then transported on dry ice to the laboratory at UC Santa Barbara.

California: Collections in California were made from 3 regions: Santa Barbara county, Los Angeles county and San Diego county. These sites are all located within the Southern California Bight; thus, they experience similar oceanographic conditions among them. Collections were made from the different regions in order to encompass any population structure that could affect physiological traits. Within each region, 4 individuals of each species were collected from the different sites. Undaria pinnatifida were collected by hand from 3 harbors where it has been introduced: Santa Barbara Harbor, Cabrillo Harbor in Los Angeles, and Coronado Island in San Diego Bay. Subtidal Egregia menziesii and Pterygophora californica were collected on SCUBA and intertidal E. menziesii were collected by hand from sites near the harbors. Specific collection locations are listed in Table 1 along with coordinates, date of collection, and temperature data obtained from NOAA buoys $\left( \pm 1.0^{\circ} \mathrm{C}\right)$, LTER moorings (Tidbit $\left.{ }^{\circledR} ; \pm 0.4^{\circ} \mathrm{C}\right)$, or i-button ${ }^{\circledR}\left( \pm 0.5^{\circ} \mathrm{C}\right)$ data loggers placed in the intertidal. Individuals were transported in coolers to the laboratory, and experiments were begun within $4 \mathrm{~h}$ of collection. Immediately upon return to the laboratory, 150 to $200 \mathrm{mg}$ tissue from each 
Table 1. Kelp collection sites and date of collection in California, USA. Temperature ranges are the average daily minimum and maximum and the absolute minimum and maximum water temperatures recorded near the indicated sites during the 2 wk prior to kelp collection. Kelp species: Undaria pinnatifida, Egregia menziesii, and Pterygophora californica. SB: Santa Barbara, LA: Los Angeles, SD: San Diego

\begin{tabular}{|c|c|c|c|c|}
\hline \multirow[t]{2}{*}{ Site } & \multirow[t]{2}{*}{ Coordinates } & \multirow[t]{2}{*}{ Collection date } & \multicolumn{2}{|c|}{ Temperature range $\left({ }^{\circ} \mathrm{C}\right)$} \\
\hline & & & Average & Absolute \\
\hline \multicolumn{5}{|l|}{ Harbor $U$. pinnatifida } \\
\hline Santa Barbara Harbor (SB) & $34^{\circ} 24^{\prime} 26^{\prime \prime} \mathrm{N}, 119^{\circ} 41^{\prime} 33^{\prime \prime} \mathrm{W}$ & 14 June 2006 & $15.4-17.7$ & $14.2-20.4$ \\
\hline Cabrillo Way Marina (LA) & $33^{\circ} 43^{\prime} 15^{\prime \prime} \mathrm{N}, 118^{\circ} 16^{\prime} 34^{\prime \prime} \mathrm{W}$ & 15 June 2006 & $19.0-20.3$ & $17.9-21.3$ \\
\hline Coronado Island (SD) & $32^{\circ} 41^{\prime} 58^{\prime \prime} \mathrm{N}, 117^{\circ} 10^{\prime} 07^{\prime \prime} \mathrm{W}$ & 12 June 2006 & $19.9-21.2$ & $19.1-21.8$ \\
\hline \multicolumn{5}{|l|}{ Intertidal E. menziesii } \\
\hline Ledbetter Beach (SB) & $34^{\circ} 23^{\prime} 47^{\prime \prime} \mathrm{N}, 119^{\circ} 42 ; 19^{\prime \prime} \mathrm{W}$ & 14 June 2006 & $14.2-17.1$ & $12.8-18.3$ \\
\hline Cabrillo Beach (LA) & $33^{\circ} 42^{\prime} 30^{\prime \prime} \mathrm{N}, 118^{\circ} 17^{\prime} 05^{\prime \prime} \mathrm{W}$ & 15 June 2006 & $19.0-20.3$ & $17.9-21.3$ \\
\hline La Jolla (SD) & $32^{\circ} 15^{\prime} 17^{\prime \prime} \mathrm{N}, 117^{\circ} 15^{\prime} 13^{\prime \prime} \mathrm{W}$ & 12 June 2006 & $17.6-20.7$ & $15.8-21.6$ \\
\hline \multicolumn{5}{|c|}{ Subtidal $E$. menziesii and P. californica } \\
\hline Refugio (SB) & $34^{\circ} 27^{\prime} 41^{\prime \prime} \mathrm{N}, 120^{\circ} 04^{\prime} 21^{\prime \prime} \mathrm{W}$ & 30 June 2007 & $15.1-17.6$ & $13.6-19.1$ \\
\hline White's Point (LA) & $33^{\circ} 42^{\prime} 52^{\prime \prime} \mathrm{N}, 118^{\circ} 19^{\prime} 06^{\prime \prime} \mathrm{W}$ & 29 June 2007 & $18.0-19.5$ & $17.0-20.5$ \\
\hline Point Loma (SD) & $32^{\circ} 41^{\prime} 01^{\prime \prime} \mathrm{N}, 117^{\circ} 15^{\prime} 29^{\prime \prime} \mathrm{W}$ & 10 July 2007 & $20.0-21.5$ & $19.3-22.8$ \\
\hline
\end{tabular}

specimen was placed in $20 \mathrm{ml}$ scintillation vials filled with filtered seawater and placed in an aluminum gradient heat block at $12,17,21.5,26.5,31,33$, and $36 \pm$ $1^{\circ} \mathrm{C}$ for $1 \mathrm{~h}$. After thermal incubation, samples were removed from heat, rinsed in $1 \times$ PBS, blotted dry, flash frozen in liquid $\mathrm{N}_{2}$, and stored at $-80^{\circ} \mathrm{C}$.

Gene expression analysis. For analysis of $h s p 70$ gene induction, total RNA was extracted, cDNA was transcribed, and quantitative PCR was run as described in Henkel \& Hofmann (2008). Primers, volumes, and melt temperatures are listed in Table 2 . Reported relative mRNA levels were calculated in the following fashion: (1) hsp70 and ribulose cycle threshold $\left(C_{t}\right)$ values were first normalized to that of the corresponding product of the cDNA standard from each plate; (2) resultant $h s p 70$ values were then normalized to the resultant ribulose values for the each sample. The ribulose gene was deemed to be an appropriate internal control because the ribulose mRNA levels did not differ significantly across heat incubations.

Statistical analysis. To compare hsp70 expression within and among species, normalized expression values at each of the incubation temperatures for each individual were divided by that individual's normalized expression value for $T_{0}=$ time zero (non-heat-shocked control). This was necessary to make comparisons among species because of the use of species-specific primers and standards, which could affect the recorded magnitude of expression, and to account for differing levels of transport stress resulting in differing initial conditions of the kelp. Two-way repeated measure ANOVAs (SigmaStat version 3.5) were conducted for each kelp population to assess for differences in hsp70 expression among sites and across temperatures. Where significant differences were found among sites or temperature incubations, Student-Newman-Keul's (SNK) post-hoc analyses were performed to clarify patterns of the heat shock response. In order to compare the heat shock response among native California kelp as well as native and invasive Undaria pinnatifida populations, 2-way repeated measure ANOVAs (JMP version 7.0) were conducted on hsp70 gene expression data normalized to $T_{0}$ to make comparisons among populations. A population was defined as a specieshabitat combination, and only those species-habitat combinations that were replicated at 3 sites were used

Table 2. Primers for quantitative PCR (qPCR), including effective volumes in $20 \mu$ reactions and melt temperatures

\begin{tabular}{|c|c|c|c|c|}
\hline & Forward & Reverse & Volume $(\mu \mathrm{l})$ & Melt temp. $\left({ }^{\circ} \mathrm{C}\right)$ \\
\hline \multicolumn{5}{|c|}{ Undaria pinnatifida } \\
\hline hsp70 & CAGGTGTACGAGGGTGAG & GTTAAGGATACCGTTGCG & 1.0 & 50 \\
\hline ribulose & CACAAGGATGTTTTTCGTTTTT & GAAGACCCCATAATTCCCAAT & 0.7 & 58 \\
\hline \multicolumn{5}{|c|}{ Egregia menziesii } \\
\hline hsp70 & AAGTTTAACCTAGACGGTATCCC & TGGTGATCTTGTTCTCCTTGC & 1.0 & 55 \\
\hline ribulose & ATGTCAAAAGGATGGGCTGT & CAGGTTCGTTTGAAGGTCGT & 1.0 & 58 \\
\hline \multicolumn{5}{|c|}{ Pterygophora californica } \\
\hline hsp 70 & AAGTTTAACCTAGACGGTATCCC & TGGTGATCTTGTTCTCCTTGC & 1.0 & 50 \\
\hline ribulose & CTATGGTTATGGCTCGTAATGAAG & GGTGTATCTGTTGAAGTGTAATCG & 1.0 & 55 \\
\hline
\end{tabular}


in the analysis (i.e. Egregia menziesii-subtidal, E. menziesii-intertidal, Pterygophora californica-subtidal, $U$. pinnatifida-harbor). SNK post-hoc tests were performed to determine which populations responded to the temperature treatments differently.

$T_{\max }$ was identified for each population and defined as the temperature at which $h s p 70$ was expressed in greatest relative proportion. $T_{\text {off }}$ then was defined as the temperature at which hsp70 expression dropped significantly (according to SNK post hoc analysis) from that at $T_{\max }$. To make comparisons of the rate of upregulation of $h s p 70$ among the species and populations, the natural log-transformed fold expression data from $12^{\circ} \mathrm{C}$ to the $T_{\max }$ were plotted against the natural $\log$ of the incubation temperatures. Linear regressions were obtained and the slope of the regression was used as a measure of the rate of up-regulation. Where we had replicates of species and habitats (Egregia menziesii and Pterygophora californica), we conducted 2-way ANOVA with the fixed factors 'species' and 'habitat' on the regression data.

\section{RESULTS}

Overall, heat shock protein gene expression analysis revealed 2 trends in the data: (1) Undaria pinnatifida seems to have a higher capacity for tolerating thermal stress than the native California species sampled in this study; and (2) variation in hsp70 expression seemed to depend more on habitat than phylogeny or geographic region. The sections below describe the analysis for each comparison; the gene expression profile is summarized in Table 3.

\section{Native and invasive Undaria pinnatifida responses}

For native Undaria pinnatifida in Japan, significant differences were observed between individuals from the floating dock at Asagiri (harbor) and the 2 intertidal sites (Fig. 1). Two-way repeated measures ANOVA results revealed that both temperature $\left(F_{5}=\right.$ 4.629, $\mathrm{MS}=9.616, \mathrm{p}=0.001)$ and site $\left(F_{2}=4.578, \mathrm{MS}=\right.$ $18.080, \mathrm{p}=0.033)$, but not the interaction $\left(F_{10}=0.830\right.$, $\mathrm{MS}=1.724, \mathrm{p}=0.602)$, were significant effects for hsp70 expression (residual $=59$ ). SNK post-hoc analysis revealed that the intertidal sites, AB-I and EO-I were statistically indistinguishable while the harbor site $(\mathrm{AB}-\mathrm{H})$ was significantly different from both. For the harbor site $(\mathrm{AB}-\mathrm{H})$ the $T_{\max }$ was $22^{\circ} \mathrm{C}$, while the 2 intertidal sites had a higher $T_{\max }$ of $26^{\circ} \mathrm{C}$ (Table 3). The rate of $h s p 70$ up-regulation (determined using linear regression) was similar between the 2 populations at Asagiri (AB-H and AB-I) and much higher in the inter-
Table 3. Undaria pinnatifida, Egregia menziesii, and Pterygophora californica. hsp70 expression parameters for native and invasive kelp species in different habitats. Up-regulation rate: slope of the linear regression of $h s p 70$ expression versus incubation temperature; $T_{\max }$ : temperature with the highest magnitude of $h s p 70$ expression; $T_{\text {off }}$ : temperature at which $h s p 70$ expression was significantly less than $T_{\text {maxi }}$ ns: not significant. AB-H and AB-I: harbor and intertidal site near the Asagiri bus station in Sumoto City, Hyogo Prefecture; EO-I: intertidal site at Etoile Oishi Park. Other abbreviations as in Table 1

\begin{tabular}{|lcccl|}
\hline Collection & $\begin{array}{c}\text { Up-regula- } \\
\text { tion rate }\end{array}$ & $T_{\max }$ & $T_{\text {off }}$ & $\begin{array}{c}\text { Collection } \\
\text { month }\end{array}$ \\
\hline Harbor & & & & \\
U. pinnatifida SD & 2.89 & 26.5 & 31 & June \\
U. pinnatifida LA & 2.80 & 26.5 & 31 & June \\
U. pinnatifida SB & 3.45 & 26.5 & 31 & June \\
U. pinnatifida Japan (AB-H) & 3.02 & 22 & 30 & March \\
Intertidal & & & & \\
U. pinnatifida Japan I (AB-I) & 2.99 & 26 & 30 & March \\
U. pinnatifida Japan II (EO-I) & 5.13 & 26 & 30 & March \\
E. menziesii SD & 1.59 & 26.5 & 31 & June \\
E. menziesii LA & 2.14 & 21.5 & ns & June \\
E. menziesii SB & 2.00 & 26.5 & 31 & June \\
Subtidal & & & & \\
E. menziesii SD & 0.84 & 33 & None & July \\
E. menziesii LA & 1.44 & 31 & None & June \\
E. menziesii SB & 1.26 & 31 & None & June \\
$P$. californica SD & 1.48 & 26.5 & None & July \\
P. californica LA & 1.25 & 26.5 & None & June \\
P. californica SB & 1.93 & 31 & None & June \\
\hline
\end{tabular}

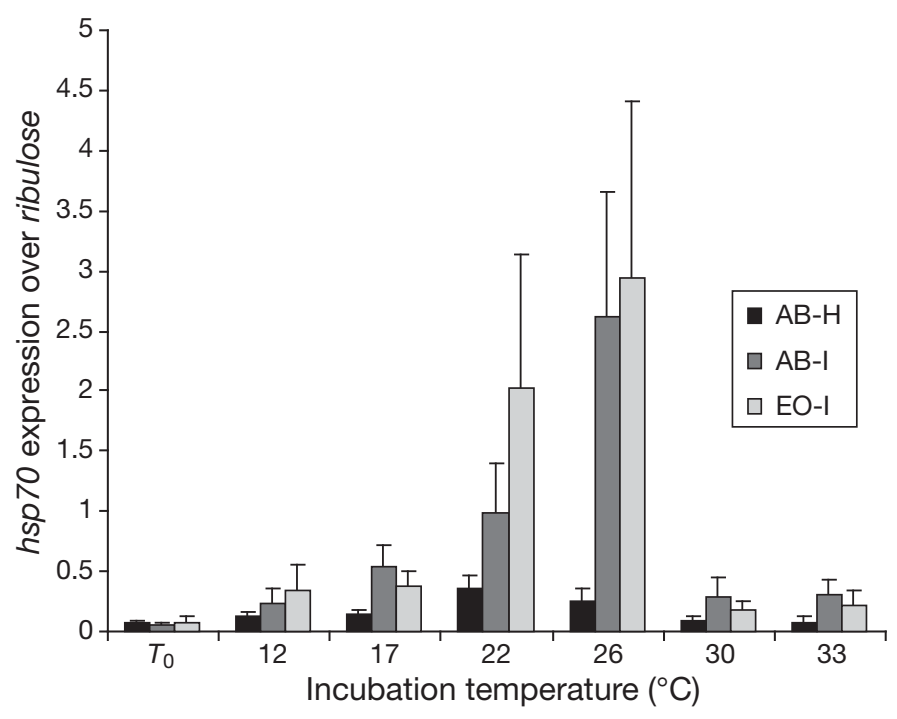

Fig. 1. Undaria pinnatifida. hsp70 expression (+SE) in native populations in Japan; $\mathrm{n}=5$ individuals for each temperature at each site. $\mathrm{AB}-\mathrm{H}$ and $\mathrm{AB}-\mathrm{I}$ : harbor and intertidal site near the Asagiri bus station in Sumoto City, Hyogo Prefecture; EO-I: intertidal site at Etoile Oishi Park. $T_{0}$ : non-heat-shocked control

tidal population collected from Etoile Oishi Park (EO-I) (Table 3), although the 2 intertidal populations had a higher magnitude of expression overall than the harbor population (Fig. 1). 


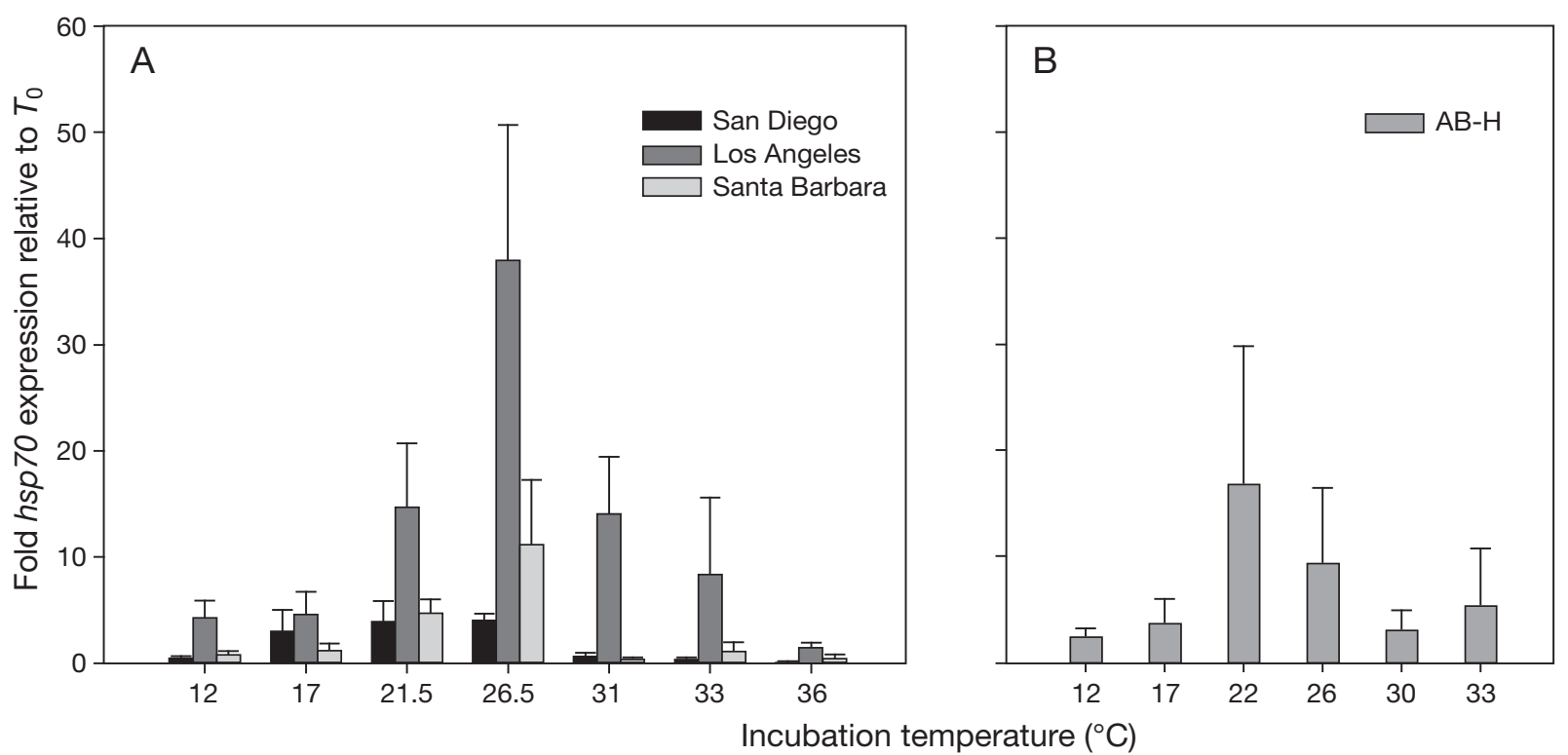

Fig. 2. Undaria pinnatifida. hsp70 expression $(+\mathrm{SE})$ relative to the non-heat-shocked control $\left(T_{0}\right)$ in $(\mathrm{A})$ populations invasive to California harbors and (B) the native Japanese harbor population. AB-H: harbor site near the Asagiri bus station in Sumoto City, Hyogo Prefecture

Undaria pinnatifida collected from California harbors exhibited an $h s p 70$ expression pattern that matched neither the harbor nor intertidal populations from Japan (Fig. 2A). The California harbor populations had a $T_{\max }$ of $26.5^{\circ} \mathrm{C}$ (like the Japanese intertidal populations); however, the shape of the induction profile was much more similar to that observed for the Japanese harbor population. The rate of $h s p 70$ upregulation in the California harbors (2.80 to 3.45$)$ was very similar to that observed in the harbor population in Japan (3.02) as well as the intertidal population from that site (2.99) (Table 3).

Two-way repeated measure ANOVA indicated that both incubation temperature and collection site were significant factors in California Undaria pinnatifida hsp70 expression ( $\log _{10}$-transformed to meet variance requirements) but there was no significant interaction effect between the 2 factors (Table 4). The significant site differences among the California harbor populations of $U$. pinnatifida were the result of the Los Angeles harbor samples having a much greater magnitude of expression than the San Diego or Santa Barbara Harbor samples. However, the site differences were likely not related to water temperatures recorded in the harbors since Los Angeles water temperatures $\left(17.9\right.$ to $\left.21.3^{\circ} \mathrm{C}\right)$ were intermediate to both Santa Barbara $\left(14.2\right.$ to $\left.20.4^{\circ} \mathrm{C}\right)$ and San Diego $\left(19.1\right.$ to $\left.21.8^{\circ} \mathrm{C}\right)$.

In order to make direct comparisons of the magnitude of response between California and Japan, quantitative PCR (qPCR) was repeated on the Japanese Undaria pinnatifida harbor population (AB-H) samples using the same standard as used for the California har- bor U. pinnatifida. We then calculated the fold hsp70 expression for each of the Japanese harbor individuals relative to $T_{0}$ expression. Japanese harbor $U$. pinnatifida responded with a very similar fold induction as California harbor U. pinnatifida (Fig. 2). When 2-way repeated measure ANOVA and SNK post-hoc analyses were conducted for the 4 ( 3 California and 1 Japan) harbor populations together, again only the Los Ange-

Table 4. Undaria pinnatifida, Egregia menziesii, and Pterygophora californica. Two-way repeated measures ANOVA results for individual species populations sampled in California. ${ }^{*}$ Significant at the 0.05 level

\begin{tabular}{|lccc|}
\hline & df & $F$ & $p$ \\
\hline Harbor $\boldsymbol{U}$. pinnatifida & & & \\
Temperature & 6,3 & 15.895 & $<0.001^{*}$ \\
Site & 2,8 & 9.603 & $0.006^{*}$ \\
Site $\times$ Temperature & 12,6 & 1.378 & 0.206 \\
& & & \\
Intertidal . menziesii & & & \\
Temperature & 6,4 & 2.865 & $0.017^{*}$ \\
Site & 2,9 & 1.456 & 0.283 \\
Site $\times$ Temperature & 12,8 & 1.288 & 0.253 \\
& & & \\
Subtidal E. menziesii & & & \\
Temperature & 6,3 & 2.258 & 0.052 \\
Site & 2,8 & 3.247 & 0.087 \\
Site $\times$ Temperature & 12,6 & 1.229 & 0.289 \\
& & & \\
Subtidal $\boldsymbol{P}$. californica & & & \\
Temperature & 6,3 & 2.388 & $0.042^{*}$ \\
Site & 2,8 & 1.429 & 0.289 \\
Site $\times$ Temperature & 12,6 & 1.242 & 0.282 \\
\hline
\end{tabular}


les population was different from the other California populations and no significant differences were observed among $\mathrm{SB}, \mathrm{SD}$, and $\mathrm{AB}-\mathrm{H}$ or between $\mathrm{AB}-\mathrm{H}$ and LA (Table 5). The magnitude of hsp70 expression when this gene was 'turned on' in both California and Japan U. pinnatifida was considerably higher than that observed for the native California species discussed below.

\section{California species responses}

Intertidal Egregia menziesii exhibited a classic bellshaped curve of hsp70 induction, peak, and decline (Fig. 3); however, the magnitude of expression was much lower overall than that observed for the various Undaria pinnatifida populations (Fig. 2A). Two-way repeated measures ANOVA indicated that temperature was a significant factor in the $h s p 70$ gene expression response among individuals, while differences observed among sites were not significant nor was there an interaction of site and temperature (Table 4). The observed $T_{\max }$ for the intertidal E. menziesii Los Angeles population was $21.5^{\circ} \mathrm{C}$ and was statistically indistinguishable (SNK post-hoc) from the response at $26.5^{\circ} \mathrm{C}$, which was the observed $T_{\max }$ for the San Diego and Santa Barbara populations; the $T_{\text {off }}$ for intertidal $E$. menziesii was observed to be $31^{\circ} \mathrm{C}$, which was approximately that which was observed for $U$. pinnatifida (Table 3). The rate of up-regulation (determined using linear regression) for intertidal E. menziesii populations ranged from 1.59 to 2.14 (Table 3).

Table 5. Undaria pinnatifida. (A) Results of 2-way repeated measures ANOVA to compare harbor-collected populations of U. pinnatifida in California and Japan. (B) Pairwise multiple comparison procedure (Student-Newman-Keuls method) comparisons for factor Site. LA: Los Angeles; SD: San Diego; SB: Santa Barbara; AB-H: harbor site near the Asagiri bus station. * Significant at the 0.05 level

\begin{tabular}{|lcccc|}
\hline (A) Source of variation & df & MS & $F$ & $p$ \\
\hline Site & 3 & 5.227 & 4.761 & $0.019^{*}$ \\
Individual(Site) & 13 & 1.116 & & \\
Temperature & 6 & 5.403 & 22.854 & $<0.001^{*}$ \\
Site $\times$ Temperature & 18 & 0.395 & 1.670 & 0.065 \\
Residual & 74 & 0.236 & & \\
Total & 114 & 0.764 & & \\
& & & & $\mathrm{p}$ \\
(B) Comparison & Diff. of means & $p$ & $q$ & \\
\hline LA vs. SD & 0.995 & 4 & 4.986 & $0.017^{*}$ \\
LA vs. SB & 0.802 & 3 & 3.965 & $0.037^{*}$ \\
LA vs. AB-H & 0.514 & 2 & 2.573 & 0.092 \\
AB-H vs. SD & 0.482 & 3 & 2.413 & 0.240 \\
AB-H vs. SB & 0.289 & 2 & 1.427 & 0.332 \\
SB vs. SD & 0.193 & 2 & 0.953 & 0.512 \\
\hline
\end{tabular}

Subtidal Egregia menziesii populations had a similar magnitude of gene expression as intertidal populations; however, the expression profile was different than for intertidal E. menziesii (Fig. 4B) with the $T_{\max }$ found at higher temperatures in the subtidal populations than the intertidal (Table 3). There appeared to be a trend in the subtidal $E$. menziesii populations with

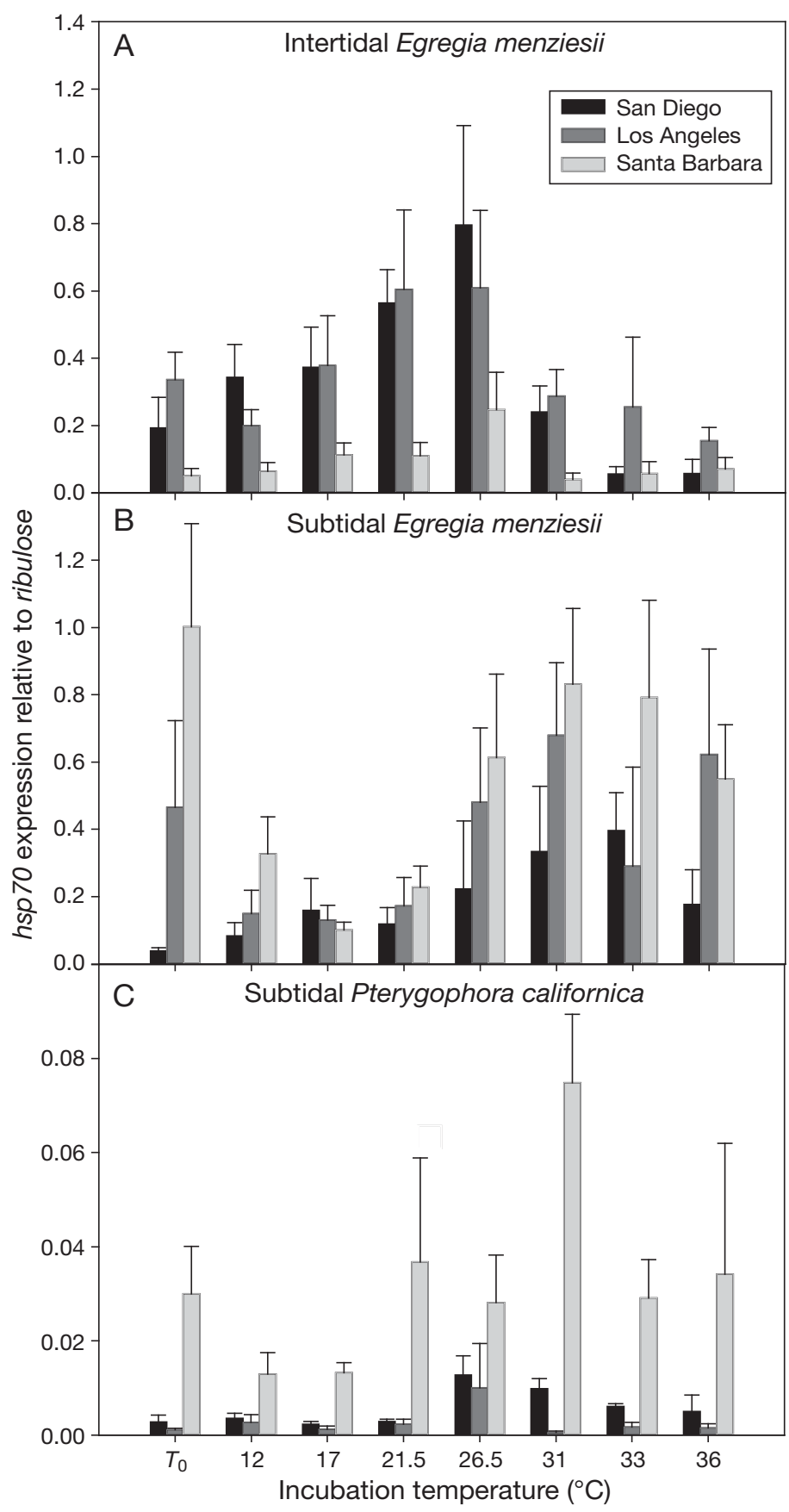

Fig. 3. Egregia menziesii and Pterygophora californica. hsp70 expression (+SE) relative to ribulose for (A) intertidal E. menziesii, (B) subtidal E. menziesii, and (C) subtidalP. californica 


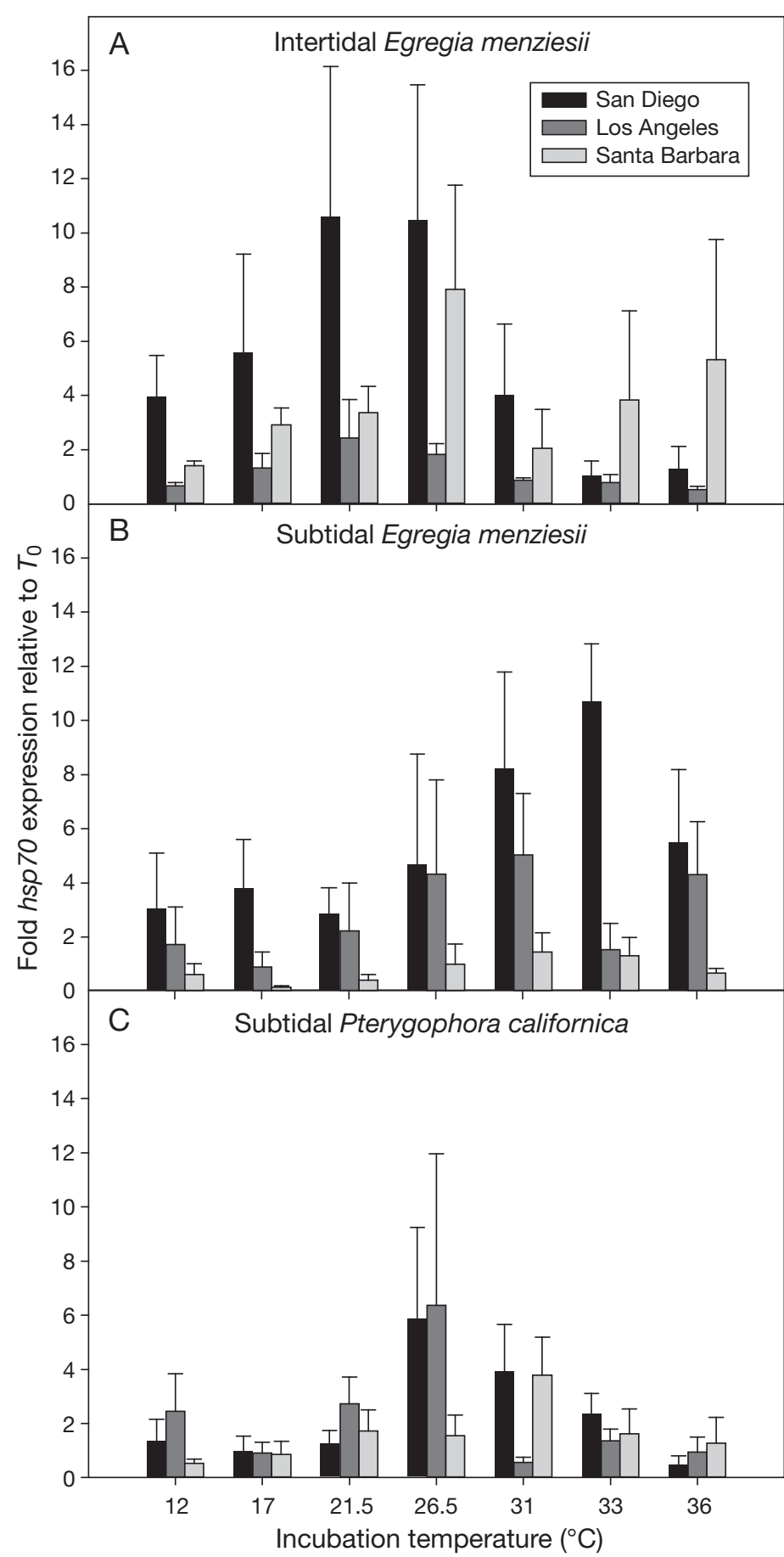

Fig. 4. Egregia menziesii and Pterygophora californica. hsp70 expression (+SE) relative to the non-heat-shocked control $\left(T_{0}\right)$ for (A) intertidal E. menziesii, (B) subtidal E. menziesii, and (C) subtidal P. californica

the magnitude of $h s p 70$ induction increasing with decreasing latitude (Fig. 4B). Temperature was a marginally significant factor and significant differences were not observed among sites (Table 4). Interestingly, no $T_{\text {off }}$ was observed in subtidal $E$. menziesii.
Table 6. Egregia menziesii. Three-way repeated measures ANOVA for E. menziesii, comparing populations from different habitats. ${ }^{*}$ Significant at the 0.05 level

\begin{tabular}{|lccl|}
\hline & df & $F$ & $\mathrm{p}$ \\
\hline Temperature & 6,12 & 3.2609 & $0.0386^{*}$ \\
Temperature $\times$ Site & 12,24 & 1.6799 & 0.1350 \\
Temperature $\times$ Habitat & 6,12 & 4.2201 & $0.0163^{*}$ \\
Temperature $\times$ Site $\times$ Habitat & 12,24 & 2.2754 & $0.0418^{*}$ \\
Site & 2,17 & 1.6408 & 0.2231 \\
Habitat & 1,17 & 0.2318 & 0.6363 \\
Site $\times$ Habitat & 2,17 & 1.0316 & 0.3777 \\
\hline
\end{tabular}

In comparing the $h s p 70$ response among all Egregia menziesii populations, there appeared to be a strong influence of the habitat. Overall, the rate of up-regulation in subtidal populations of E. menziesii was lower (ranging from 0.84 to 1.44 ; Table 3 ) than the intertidal populations. Three-way repeated measure ANOVA with temperature, site, and habitat as factors resulted in a significant interaction effect between habitat and temperature as well as habitat, site, and temperature (Table 6), indicating that populations from different habitats responded differently to the temperature treatments.

Subtidal Pterygophora californica exhibited a similar magnitude (Fig. 4C) and rate of up-regulation (Table 3) of hsp70 expression to subtidal populations of Egregia menziesii. In San Diego and Los Angeles, P. californica had lower observed $T_{\max }$ than subtidal E. menziesii, while the $T_{\max }$ were the same in Santa Barbara (Table 3). Also similar to the subtidal E. menziesii, no $T_{\text {off }}$ was observed for subtidal $P$. californica (Table 3 ). Temperature was identified as a significant factor in hsp70 gene expression for subtidal $P$. californica; however, differences among populations were not statistically significant (Table 4).

Overall, both native and invasive populations of Undaria pinnatifida were significantly different than native California populations. Two-way repeated measures ANOVA followed by SNK post-hoc analysis indicated that at $22^{\circ} \mathrm{C}(\mathrm{p}=0.002)$ and $26^{\circ} \mathrm{C}(\mathrm{p}=0.030)$ all populations of $U$. pinnatifida were significantly different from all populations of California native species; however, no significant differences among native California kelp populations were observed. Based on the comparisons of the rate of up-regulation of $h s p 70$ among species and populations, it appeared that habitat drove similarity in hsp70 gene expression (Table 3): subtidal California kelp populations had the slowest up-regulation rate, while native California intertidal populations of the same species had faster rates. Harbor populations of $U$. pinnatifida had still faster upregulation, while the intertidal $U$. pinnatifida from Etoile Oishi had the fastest up-regulation rate of all. 
Where we had replicates of species and habitats (Egregia menziesii and Pterygophora californica) 2-way ANOVA on the regression data indicated that habitat ( $p=0.029)$ but not species $(p=0.196)$ was a significant factor.

\section{DISCUSSION}

\section{Invasive versus native responses}

We hypothesized that California populations of Undaria pinnatifida would be less variable than native Japanese populations due to founder effects which might limit the genetic variability within and across populations in the new range. This hypothesis is supported by studies which indicate invasive populations of $U$. pinnatifida in California are a single haplotype (Voisin et al. 2005, Uwai et al. 2006). Within California, the 3 populations did respond to temperature with the same pattern of $h s p 70$ expression, the only difference being that Los Angeles $U$. pinnatifida populations had a greater magnitude of expression. While the Japanese populations demonstrated greater differences in the response among populations, this was due to the fact that more variable habitats were sampled. Within a habitat (intertidal) in Japan, the responses were indistinguishable. Thus, we were not able to conclude from this study whether invasive populations of $U$. pinnatifida are more (leading to their invasiveness) or less (due to founder effects) variable than native populations. Since the magnitude of expression in the Japanese harbor population was extremely similar to the magnitude of expression in the San Diego and Santa Barbara, California, harbor populations, it does not seem that the invasive populations of $U$. pinnatifida are any more 'robust' in their ability to up-regulate the heat shock pathway in response to thermal stress than are native $U$. pinnatifida. This lack of difference between native and introduced populations is similar to trends observed for native and invasive tropical shrub populations in terms of growth rates, photosynthetic rates, or biomass allocation (DeWalt et al. 2004).

The invasive species did exhibit a greater magnitude of response overall than the 2 native California species sampled. This trait, resulting in a greater capacity for dealing with thermal stress, may be what contributes to the widespread success of Undaria pinnatifida on nearly every continent to date, as the amount of heat shock protein expression is positively correlated with thermotolerance (Krebs \& Feder 1998). The greater expression of $h s p 70$ in $U$. pinnatifida seems to be a trait of the species as a whole since the magnitude of expression was similarly high from both California and Japan populations collected from harbor sites and the intertidal Japanese populations exhibited still greater expression. Furthermore, the rates of up-regulation for all populations of $U$. pinnatifida were higher than those observed for native California kelp species, even when collected from similar habitats.

Greater hsp70 mRNA expression may be achieved via 2 main mechanisms. First, Undaria pinnatifida may contain more copies of the $h s p 70$ gene than the other species sampled in this study. Species of Drosophila with cosmopolitan distributions have greater hsp70 copy number, express more Hsp70 protein, and are more thermotolerant than are other members (Krebs \& Bettencourt 1999). Furthermore, laboratory strains of D. melanogaster that contained additional hsp 70 gene copies were found to have increased Hsp70 concentrations and stress tolerance (Welte et al. 1993, Feder et al. 1996, Roberts \& Feder 2000). A second mechanism for greater expression of hsp $70 \mathrm{mRNA}$ in $U$. pinnatifida may be variation in the heat shock factor rather than more copies of the gene. This mechanism is discussed in detail in the following section.

\section{Habitat differences}

Habitat differences observed in Undaria pinnatifida in Japan are likely due to population level variability in the heat shock response. The 2 intertidal populations located further apart exhibited statistically indistinguishable induction profiles and magnitude of expression, while the paired intertidal and harbor populations (located approximately $5 \mathrm{~m}$ apart) exhibited different expression profiles and magnitude. This suggests that local acclimatization to habitat-specific environmental conditions may have a more significant effect on the induction response than shared genetics, as the paired populations likely have a shared gene pool due to their close proximity. Such local acclimatization is to be expected since species inhabiting intertidal habitats generally encounter greater temperature variability than those that are continually submerged; thus, they must be able to tolerate or respond to temperature fluctuations. This may result in different physiological phenotypes between intertidal and subtidal species or populations, as the pattern of the heat shock response can be set by acclimation to different environmental conditions (Barua \& Heckathorn 2004). The fast up-regulation rate observed in the intertidal $U$. pinnatifida population at Etoile Oishi Park (EO-I) may be a response to the more fluctuating conditions found in the intertidal, while the greater magnitude of expression observed in intertidal $U$. pinnatifida populations relative to the harbor population may indicate a greater capacity for dealing with overall temperature increases. 
Within the California native species, Egregia menziesii, hsp70 expression exhibited a significant response to the interaction of habitat and temperature, indicating that populations from different habitats responded to temperature differently. This can be seen in the specific induction parameters where subtidal E. menziesii populations had lower up-regulation rates, higher $T_{\text {max }}$ and did not exhibit a $T_{\text {off }}$ as compared to intertidal populations. (The lack of significance for habitat as a single factor is likely due to the fact that overall magnitude of $h s p 70$ expression was similar between the 2 habitats.) E. menziesii exhibits morphological variability among sites that seems to be a response to environmental conditions (Henkel et al. 2007) and exhibited population specific responses to heat stress that varied with latitude in previous hsp70 investigations (Henkel \& Hofmann 2008). Thus, the significant differences observed in this physiological measure between habitats in our study were not unexpected.

The other native species, Pterygophora californica, had not been previously investigated in terms of the heat shock response, so the findings in this work were novel. $P$. californica is in the same kelp group as Undaria pinnatifida (Lane et al. 2006); however, it shares the same range and subtidal habitat as Egregia menziesii, which is regularly used as an out-group to all other kelp species (Lane et al. 2006). Thus, we were interested to learn whether the expression profile of $P$. californica was more similar to the closely related $U$. pinnatifida or if it better matched the pattern for populations of a distantly related species in the same habitat. The expression pattern for $P$. californica was not significantly different from that of E. menziesii collected from the same habitat; however, the hsp70 expression parameters for $P$. californica were quite different from the closely related $U$. pinnatifida. This large difference was likely due both to the fact that they were collected from different habitats and a result of the apparent greater thermotolerance of the introduced species.

The habitat-specific heat shock response observed in this study in both Undaria pinnatifida and Egregia menziesii is consistent with a number of studies in which differences were seen within the same species collected from different habitats (Helmuth \& Hofmann 2001, Halpin et al. 2002, Manitasevic et al. 2007), latitudes (Osovitz \& Hofmann 2005, Fangue et al. 2006), or seasons (Roberts et al. 1997, Buckley et al. 2001, Hamdoun et al. 2003, Manitasevic et al. 2007). This pattern was previously observed between harbor and subtidal populations of $U$. pinnatifida subjected to a period of constant temperatures in the laboratory followed by experiments similar to those in this work (Henkel \& Hofmann 2008). Thus, in kelps, while aspects of the heat shock response might be tuned to the local envi- ronment, it does not appear to be easily altered by short-term exposure to different conditions such as attempted laboratory acclimations.

Inducible heat shock protein expression in all organisms is regulated by heat shock transcription factors (HSFs); this is referred to as the cellular thermometer model of gene regulation since heat shock proteins play an autoregulatory role in governing their own synthesis by determining the levels of free HSFs that exist in the cell (Tomanek \& Somero 2002). The cellular thermometer model predicts that elevated concentrations of HSFs would, other things such as Hsp70 protein levels being equal, favor lower $T_{\text {on }}$ values for hsp gene transcription because of larger amounts of free HSFs for available to bind to the heat shock element and promote transcription (Tomanek \& Somero 2002). Cellular pools of HSFs are known to vary among species (Tomanek \& Somero 2002), and greater amounts of HSFs in Undaria pinnatifida could be what drives its greater expression of hsp 70 than the sampled native species. There has been conflicting evidence whether HSFs are subject to thermal acclimation/ acclimatization within a species (see Buckley et al. 2001, Buckley \& Hofmann 2002, Tomanek \& Somero 2002), but evidence from Buckley \& Hofmann (2004) suggests that endogenous levels of HSF can be changed by acclimation to different environmental conditions. In our system of different kelp populations with differing degrees of stressful thermal history (intertidal > harbor > subtidal), increased concentrations of HSF leading to increased rates of HSF activation and $h s p 70$ synthesis would be a mechanism by which populations more frequently exposed to thermal stress could have a faster rate of induction and a lower $T_{\max }$ as the need for more chaperone proteins is met more quickly.

Alternatively, differences in $h s p 70$ expression may lie in the activation temperature of HSFs as observed in Gillichthys mirabilis (Buckley \& Hofmann 2004) and in Mytilus californianus (Buckley et al. 2001). It may be that HSFs bind to the heat shock element (HSE) at a lower temperature under certain conditions and are kept inactive on the promoter until a stressful temperature is reached. Thus, differences in induction temperature among populations would be a result of differences in the activation of the HSE where intertidal populations may have developed mechanisms for activating pre-bound HSF more quickly. Future work in this system should include measuring both HSF and Hsp70 protein concentrations to have a more complete picture of the mechanisms driving the hsp70 expression patterns seen in this study. If such studies revealed that intertidal populations have high endogenous levels of the HSF, it would provide an explanation for the lower temperature of $h s p 70$ induction. How- 
ever, if differences in HSF are not seen among populations with different thermal histories, the controlling steps that underlie the adjustment in gene transcription induction probably occur after the HSF has bound to the promoter.

In the present study, we had the unique opportunity to make comparisons among species and habitats to see if phylogeny or habitat seemed to be the stronger determinant of the pattern of heat shock response. We found that the heat shock response seems to be shaped by environment as the response was more similar within habitat than within species or closely related species. While this study is one of the first to make cross-species and cross-habitat comparisons, our findings have been long predicted. Krebs \& Bettencourt (1999) stated, 'Expression in each species may differ for many reasons, or be similar for different reasons; in the end, I predict that variation in Hsp70 expression will follow more microclimatic differences rather than either large-scale phylogenetic or climatic patterns.' Experimental tests of the degree of plasticity of the response between native and invasive species and populations will contribute to the discussion of whether invasive species or populations indeed possess special characters or greater plasticity and lead to greater understanding of how invasive species persist and proliferate and of the dynamics between native and invasive species.

Acknowledgements. The research described in this paper has been funded primarily by the United States Environmental Protection Agency (EPA) by a Science to Achieve Results (STAR) Graduate Fellowship Program grant to S.K.H. EPA has not officially endorsed this publication and the views expressed herein may not reflect the views of the EPA. Additional funds were obtained from a PISCO grant to G.E.H. This is contribution number 344 from PISCO, the Partnership for Interdisciplinary Studies of Coastal Oceans, funded primarily by the Gordon and Betty Moore Foundation and David and Lucile Packard Foundation. The authors acknowledge W. J. Black for laboratory assistance in Japan and M. L. Zippay for collection assistance in California.

\section{LITERATURE CITED}

Abbott IA, Hollenberg GJ (1976) Marine algae of California. Stanford University Press, Stanford, CA

Aguilar-Rosas R, Aguilar-Rosas LE, Ávila-Serrano G, MarcosRamírez R (2004) First record of Undaria pinnatifida (Harvey) Suringar (Laminariales, Phaeophyta) on the Pacific coast of Mexico. Bot Mar 47(3):255-258

Barua D, Heckathorn SA (2004) Acclimation of the temperature set-points of the heat-shock response. J Therm Biol 29:185-193

Bosch TCG, Krylow SM, Bode HR, Steele RE (1988) Thermotolerance and synthesis of heat shock proteins: These responses are present in Hydra attenuate but absent in Hydra oligactis. Proc Natl Acad Sci USA 85:7927-7931

Bossdorf O, Prati D, Auge H, Schmid B (2004) Reduced com- petitive ability in an invasive plant. Ecol Lett 7:346-353 Boudouresque CF, Gerbal M, Knoepfflerpeguy M (1985) Japanese algae Undaria pinnatifida (Phaeophyceae, Laminariales) in the Mediterranean. Phycologia 24:364-366

- Buckley BA, Hofmann GE (2002) Thermal acclimation changes DNA-binding activity of heat shock factor 1 (HSF1) in the goby Gillichthys mirabilis: implications for plasticity in the heat-shock response in natural populations. J Exp Biol 205:3231-3240

Buckley BA, Hofmann GE (2004) Magnitude and duration of thermal stress determine kinetics of hsp gene regulation in the goby Gillichthys mirabilis. Physiol Biochem Zool 77:570-581

Buckley BA, Owen ME, Hofmann GE (2001) Adjusting the thermostat: the threshold induction temperature for the heat-shock response in intertidal mussels (genus Mytilus) changes as a function of thermal history. J Exp Biol 204: 3571-3579

Campbell SJ, Bite JS, Burridge TR (1999) Seasonal patterns in the photosynthetic capacity, tissue pigment and nutrient content of different developmental stages of Undaria pinnatifida (Phaeophyta: Laminariales) in Port Phillip Bay south-eastern Australia. Bot Mar 42:231-241

Casas GN, Piriz ML (1996) Surveys of Undaria pinnatifida (Laminariales, Phaeophyta) in Golfo Nuevo, Argentina. Hydrobiologia 326-327:213-215

Casas G, Scrosati R, Piriz ML (2004) The invasive kelp Undaria pinnatifida (Phaeophyceae, Laminariales) reduces native seaweed diversity in Nuevo Gulf (Patagonia, Argentina). Biol Invasions 6:411-416

Choi HG, Kim YS, Lee SJ, Park EJ, Nam KW (2005) Effects of daylength, irradiance and settlement density on the growth and reproduction of Undaria pinnatifida gametophytes. J Appl Phycol 17:423-430

> Dean PR, Hurd CL (2007) Seasonal growth, erosion rates, and nitrogen and photosynthetic ecophysiology of Undaria pinnatifida (Heterokontophyta) in southern New Zealand. J Phycol 43:1138-1148

> DeWalt SJ, Denslow JS, Hamrick JL (2004) Biomass allocation, growth, and photosynthesis of genotypes from native and introduced ranges of the tropical shrub Clidemia hirta. Oecologia 138:521-531

> Dukes JS, Mooney HA (1999) Does global change increase the success of biological invaders? Trends Ecol Evol 14: $135-139$

Fangue NA, Hofmeister M, Schulte PM (2006) Intraspecific variation in thermal tolerance and heat shock protein gene expression in common killifish, Fundulus heteroclitus. J Exp Biol 209:2859-2872

> Feder ME, Cartano NV, Milos L, Krebs RA, Lindquist SL (1996) Effect of engineering $h s p 70$ copy number on Hsp70 expression and tolerance of ecologically relevant heat shock in larvae and pupae of Drosophila melanogaster. J Exp Biol 199:1837-1844

Fletcher RL, Manfredi C (1995) The occurrence of Undaria pinnatifida (Phaeophyceae, Laminariales) on the south coast of England. Bot Mar 38:355-358

Floc'h JY, Pajot R, Mouret V (1995) Propagation of the Japanese brown alga Undaria pinnatifida (Harvey) Suringar along the French Atlantic coasts. Cryptogam Algol 16:157-158

Forrest BM, Brown SN, Taylor MD, Hurd CL, Hay CH (2000) The role of natural dispersal mechanisms in the spread of Undaria pinnatifida (Laminariales, Phaeophyceae). Phycologia 39:547-553

Gehring WJ, Wehner R (1995) Heat shock protein synthesis and thermotolerance in Cataglyphis, an ant from the Sahara Desert. Proc Natl Acad Sci USA 92:2994-2998 
Goni I, Gudiel-Urbano M, Saura-Calixto F (2002) In vitro determination of digestible and unavailable protein in edible seaweed. J Sci Food Agric 82:1850-1854

Halpin PM, Sorte CJ, Hofmann GE, Menge BA (2002) Patterns of variation in levels of Hsp70 in natural rocky shore populations from microscales to mesoscales. Integr Comp Biol 42:815-824

Hamdoun AM, Cheney DP, Cherr GN (2003) Phenotypic plasticity of HSP70 and HSP70 gene expression in the Pacific Oyster (Crassostrea gigas): implications for thermal limits and induction of thermal tolerance. Biol Bull 205:160-169

Hay CH, Villouta E (1993) Seasonality of the adventive Asian kelp Undaria pinnatifida in New Zealand. Bot Mar 36: 461-476

Helmuth BST, Hofmann GE (2001) Microhabitats, thermal heterogeneity, and patterns of physiological stress in the rocky intertidal zone. Biol Bull 201:374-384

> Henkel S, Hofmann G (2008) Differing patterns of hsp 70 gene expression in invasive and native kelp species: evidence for acclimation-induced variation. J Appl Phycol 20:915-924

Henkel SK, Hofmann GE, Whitmer AC (2007) Morphological and genetic variation in Egregia menziesii over a latitudinal gradient. Bot Mar 50:159-170

> Hierro JL, Maron JL, Callaway RM (2005) A biogeographical approach to plant invasions: the importance of studying exotics in their introduced and native range. J Ecol 93: $5-15$

Ishikawa Y (1993) A simple method for growth estimation of blades in Undaria pinnatifida. Nippon Suisan Gakkaishi 59:1331-1336

> Jurkovic N, Kolb N, Colic I (1995) Nutritive value of marine algae Laminaria japonica and Undaria pinnatifida. Nahrung-Food 39:63-66

Kimura H, Notoya M (1996) Suitable time and depth of outplant seedlings for forced cultivation of Undaria undarioides (Yendo) Okamura at Tanabe bay in Wakayama Prefecture, Japan. Nippon Suisan Gakkaishi 62:723-726

Kolar CS, Lodge DM (2001) Progress in invasion biology: predicting invaders. Trends Ecol Evol 16:199-204

Krebs RA, Bettencourt BR (1999) Heat shock protein variation and the evolution of thermotolerance in Drosophila. Am Zool 39:910-919

Krebs RA, Feder ME (1998) Experimental manipulation of the cost of thermal acclimation in Drosophila melanogaster. Biol J Linn Soc 63:593-601

> Lane CE, Mayes C, Druehl LD, Saunders GW (2006) A multigene molecular investigation of the kelp (Laminariales, Phaeophyceae) supports substantial taxonomic re-organization. J Phycol 42:493-512

Lindquist S (1986) The heat-shock response. Annu Rev Biochem 55:1151-1191

> Liu JX, Dong LF, Shen YQ, Wu CY (2004) Effect of light period on egg-discharge of gametophyte clones of Undaria pinnatifida (Phaeophyta). J Appl Phycol 16:519-521

Mack RN, Simberloff D, Lonsdale WM, Evans H, Clout M, Bazzaz FA (2000) Biotic invasions: causes, epidemiology, global consequences, and control. Ecol Appl 10:689-710

Manitasevic S, Dunderski J, Matic G, Tucic B (2007) Seasonal variation in heat shock proteins Hsp70 and Hsp90 expression in an exposed and a shaded habitat of Iris pumila. Plant Cell Environ 30:1-11

Mooney HA, Cleland EE (2001) The evolutionary impact of invasive species. Proc Natl Acad Sci USA 98:5446-5451

Neubert MG, Parker IM (2004) Projecting rates of spread for invasive species. Risk Anal 24:817-831

Oh SH, Koh CH (1996) Growth and photosynthesis of Undaria pinnatifida (Laminariales, Phaeophyta) on a cultivation ground in Korea. Bot Mar 39:389-393
Osovitz CO, Hofmann GE (2005) Thermal history-dependent expression of the $h s p 70$ gene in purple sea urchins: biogeographic patterns and the effect of temperature acclimation. J Exp Mar Biol Ecol 327:134-143

Parker IM, Rodriguez J, Loik ME (2003) An evolutionary approach to understanding the biology of invasions: local adaptation and general-purpose genotypes in the weed Verbascum thapsus. Conserv Biol 17:59-72

Perez R, Durand P, Kaas R, Barbaroux O and others (1988) Undaria pinnatifida on the French coasts. Cultivation method, biochemical composition of the sporophyte and the gametophyte. In: Staedler T, Mollion J, Verdus MC, Karamanos Y, Morvan H, Christiaen D (eds) Algal biotechnology. Elsevier, London, p 315-328

Roberts SP, Feder ME (2000) Changing fitness consequences of hsp70 copy number in transgenic Drosophila larvae undergoing natural thermal stress. Funct Ecol 14:353-357

Roberts DA, Hofmann GE, Somero GN (1997) Heat-shock protein expression in Mytilus californianus: acclimatization (seasonal and tidal-height comparisons) and acclimation effects. Biol Bull 192:309-320

Saito Y (1956) An ecological study of Undaria pinnatifida SUR. II. On the influence of the environmental factors upon the maturity of gametophytes and early development of sporophytes. Bull Jpn Soc Sci Fish 22:235

Saito Y (1975) Undaria. In: Tohida J, Hhirose J (eds) Advances in phycology in Japan. The Hague, p 304-320

Sakai AK, Allendorf FW, Holt JS, Lodge DM, Molofsky J, With KA (2001) The population biology of invasive species. Annu Rev Ecol Syst 32:305-332

Saunders BM, Hope C, Pascoe VM, Martin LS (1991) Characterization of stress protein response in 2 species of Colisella limpets with different temperature tolerances. Physiol Zool 64:1471-1489

Schaffelke B, Campbell ML, Hewitt CL (2005) Reproductive phenology of the introduced kelp Undaria pinnatifida (Phaeophyceae, Laminariales) in Tasmania, Australia. Phycologia 44:84-94

Silva PC, Woodfield RA, Cohen AN, Harris LH, Goddard JHR (2002) First report of the Asian kelp Undaria pinnatifida in the Northeastern Pacific Ocean. Biol Inv 4(3):333-338

Sliwa C, Johnson CR, Hewitt CL (2006) Mesoscale dispersal of the introduced kelp Undaria pinnatifida attached to unstable substrata. Bot Mar 49:396-405

> Stachowicz JJ, Byrnes JE (2006) Species diversity, invasion success, and ecosystem functioning: disentangling the influence of resource competition, facilitation, and extrinsic factors. Mar Ecol Prog Ser 311:251-262

> Stachowicz JJ, Terwin JR, Whitlatch RB, Osman RW (2002) Linking climate change and biological invasions: ocean warming facilitates nonindigenous species invasions. Proc Natl Acad Sci USA 99:15497-15500

Thornber CS, Kinlan BP, Graham MH, Stachowicz JJ (2004) Population ecology of the invasive kelp Undaria pinnatifida in California: environmental and biological controls on demography. Mar Ecol Prog Ser 268:69-80

Tomanek L, Somero GN (2002) Interspecific- and acclimationinduced variation in levels of heat-shock proteins 70 (hsp70) and 90 (hsp90) and heat-shock transcription factor-1 (HSF1) in congeneric marine snails (genus Tegula): implications for regulation of hsp gene expression. J Exp Biol 205:677-685

- Uwai S, Nelson W, Neill K, Wang WD and others (2006) Genetic diversity in Undaria pinnatifida (Laminariales, Phaeophyceae) deduced from mitochondria genes-origins and succession of introduced populations. Phycologia 45:687-695

Voisin M, Engel CR, Viard F (2005) Differential shuffling of 
native genetic diversity across introduced regions in a brown alga: aquaculture vs. maritime traffic effects. Proc Natl Acad Sci USA 102:5432-5437

- Welte MA, Tetrault JM, Dellavalle R, Lindquist S (1993) A new method for manipulating transgenes: engineering heat tolerance in a complex, multicellular organism. Curr Biol 3:842-853

White CN, Hightower LE, Schultz JR (1994) Variation in heat-

Editorial responsibility: Hans Heinrich Janssen,

Oldendorf/Luhe, Germany shock proteins among species of desert fishes (Poeciliidae, Poeciliopsis). Mol Biol Evol 11:106-119

Williamson M (1996) Biological invasions. Chapman Hall, London

Williamson MH, Fitter A (1996) The characters of successful invaders. Biol Conserv 78:163-170

Yanagi T (1984) Seasonal variation of water temperature in the Seto Inland Sea. J Oceanogr Soc Jpn 40:445-450

Submitted: July 24, 2008; Accepted: April 2, 2009

Proofs received from author(s): May 29, 2009 